\title{
Effect of experimental pneumoconiosis on lipid peroxidation and the activity of enzymes the antioxidant protection system in albino rats
}

\author{
O. Oliynyk ${ }^{1}$, A. Slifirczyk ${ }^{1}$, O. Venger ${ }^{2}$ \\ ${ }^{1}$ Pope John Paul II State School of Higher Education, Biała Podlaska, Poland; \\ ${ }^{2}$ I.Horbachevsky Ternopil National Medical University, Ukraine; \\ e-mail: alexanderoliynyk8@gmail.com
}

Pneumoconiosis $(P c)$ are interstitial pulmonary diseases of professional genesis, caused by long-term inhalation of high dust concentrations. Pc affects from 26.6 to 53 percent of professional workers associated with dust contamination. The peculiarity of the course of Pc is in its incurability and irreversibility. Pc was modeled in 72 albino rats by endotracheal injection of a suspension of coal according to its own modification of the technique O.Yu. Nikolenko. The activity of lipid peroxidation and enzymes of the antioxidant protection system was related to the sickness period. The development of experimental Pc led to the increasing level of malonic dialdehyde in 1.68-3.05 times in the blood, and also increase in the level of diene conjugates, and triene conjugates 2.43-5.63 times, depending on the duration of the disease. 1.77-4.42 times decrease in catalase, superoxide dismutase, and glutathione peroxidase activity, alongside with 1.56-2.02 times increase in glutathione reductase activity, depending on the disease phase, occurred. The content of reduced glutathione decreased in proportion to the duration of the disease. Initiation of lipid peroxidation and suppressed activity of antioxidant protection system enzymes may be among the pathogenic mechanisms of experimental Pc development.

Key words: experimental pneumoconiosis; lipid peroxidation; catalase; superoxide dismutase; glutathione peroxidase; glutathione reductase.

\section{INTRODUCTION}

In the current structure of chronic occupational diseases, Pneumoconiosis $(\mathrm{Pc})$ is ranking second in terms of prevalence, the average for the last 5 years $33.6-36.1 \%$ of the total number of cases. $26.6-53 \%$ of the workers dealing with dust pollution are afflicted by Pc [1]. According to different authors, average $5-6 \%$ of the total of first found occupational diseases have been diagnosed Pc [2]. Recently, the number of recorded Pc cases has been remaining stable that can be attributed to the two factors. On the one hand, improving working conditions at the dust-polluted production facilities lead to morbidity reduction. On the other hand, with Pc diagnostics improving, the total number of diagnosed cases increased [3].

(C) O. Oliynyk, A. Slifirczyk, O. Venger
Capable and skilled workers being prone to the disease, the problem of Pc morbidity should be regarded both medically and socioeconomically. $\mathrm{Pc}$ is fraught with occupational disability and long-term disability payments and, therefore, to economic losses. The sickness course also depends on the presence of associated diseases and individual systemic sensitivity. Pc irreversibility, propensity for progression, and frequent complications in the form of specific (tuberculosis) and nonspecific pulmonary diseases, as well as of extrapulmonary processes, alongside with lacking effective treatment methods make studying of pathogenesis crucial, the latter being intertwined with the issues of general pathology, biochemistry, physiology, and other basic branches of medicine. Increased lipid peroxidation is known to be a universal 
pathogenic mechanism of a number of pathologic processes, including Pc [4]. The risk of Pc development depends on the period of sickness, the intensity of the dust factor, and dust fibrogenicity degree. However, Pc development is not always caused by the above-mentioned factors only. Hereditary factor is known to be involved in the onset of occupational diseases to some extent. This is demonstrated by the fact that the pathogenic effect of industrial dust is not comprehensive, and respiratory diseases, if any, are different in terms and severity [5]. According to Imanaka, 2017 [6], a factor that can determine individual systemic sensitivity to the fibrogenic action of the dust is the state of the antioxidant protection system. A hereditary propensity to Pc development is assumed to depend, in part, on the activity of the mentioned enzymes, since it affects the state of the immune system $[7,8]$.

Available sources on the activity of the enzymes of antioxidant protection system are contradictory, some of them indicating increasing [9], while the others - decreasing activity [10]. The authors mentioned above emphasize the need for a more detailed study of antioxidant protection system in Pc. To date, we have not found works dealing with lipid peroxidation and antioxidant protection system in $\mathrm{Pc}$, depending on the sickness period or its phase. The study of their state in conditions experimental Pc is justified with regard to the future development of corrective therapy methods.

The objective of this research is the study of lipid peroxidation and antioxidant protection system activity in albino rats, depending on the period of experimental Pc.

\section{METHODS}

50 male albino Wistar rats (body weight 200$250 \mathrm{~g}$ ) were used in the experiment. Pneumoconiosis was simulated on our own modification of the technique O. Yu. Nikolenko, 2013 [11]. For this purpose, fixed on the back under surface ether anaesthesia animals were injected $250 \mathrm{mg} / \mathrm{kg}$ of coal suspension with a blunt needle for spinal anaesthesia (G22). O.Yu. Nikolenko's method included the use of intratracheal injection of the coal dust regardless of a rat body weight. The dose of $250 \mathrm{mg} / \mathrm{kg}$ was chosen according to recommendations by G. Hatch, 1984 [12], who had proved that the dose indicated results in morphologic manifestations of initial pneumoconiosis, developing into extensive disease within a 12-week installation.

To make coal suspension we used laboratory vibration eraser 75Т-ДРМ making possible to obtain suspension of fine-dispersed coal particles up to $5 \mu \mathrm{m}$. In our opinion, it is essential since numerous studies have proved that only $5 \mu \mathrm{m}$ and smaller dust particles penetrate into the alveoli. Prior to endobronchial loading, the dust was sterilized at $105^{\circ} \mathrm{C}$ and then processed on the ultrasound dispergator УЗДН$2 \mathrm{~T}$ (frequency $44 \mathrm{kHz}$ ), another modification of O.Yu. Nikolenko's methodology. An auricular otolaryngological funnel was used for the fixation of the rat pharynx. Promptly after injection of the suspension, the rats were positioned upright.

The terms introduction animals of coal dust were determined, based on the following considerations [13]. The average length of a lab rat life cycle is about 36 months or 3 years, which is roughly correlated to 72-year human age as 1:24. Based on this extrapolation, 1 week of rat life is comparable on the average to 6 months of human life, and 20-year human age prior to working at the mine roughly matches 8-month rat age. In our research, the term of animals' priming with coal dust was 1, 3, 6, and 12 weeks, which is appropriate to correlate with $0.5,1.5,3.0$, and 6-year man's work at the mine, respectively. These terms match early Pc manifestations [13].

The rats were kept in Fengshi plastic cages, 4 in each, on the litter of wooden chips. Light conditions: 12 hours - light, 12 hours dark. Temperature regime $-19-25^{\circ} \mathrm{C}$. Relative humidity $-50-70 \%$. Temperature and humidity indices were taken daily. Ventilation was controlled with the anemometer and by 
measuring carbon dioxide and ammonia air content. Ventilation regime, providing 15-room volume per hour, carbon dioxide concentration up to 0.15 volume percent, and ammonia - up to $0.001 \mathrm{mg} / 1$, was set. The rats were fed twice a day, water available ad libitum.

The animals were blindly randomized into 5 groups $(\mathrm{n}=10)$ : 1) intact rats; 2) 1-week priming with coal dust; 3 ) 3-week priming; 4) 6-week priming; 5) 12-week priming. The blood content of lipid peroxidation (LP) markers: malonic dialdehyde (MDA), as well as of diene conjugates (DC), and triene conjugates (TC) was determined [14]. Studied in the blood serum was the activity of antioxidant protection system enzymes: catalase (CAT), superoxide dismutase (SOD), glutathione reductase (GR), glutathione peroxidase (GPR), and reduced glutathione ( $R G)$. To collect blood samples, the animals were anaesthetized with intraperitoneal propofol injection (4 mg/ $\mathrm{kg}$ ), and then laparotomized. The blood was taken through diaphragm puncture from the abdominal cavity and left ventricle. Then the wound in the abdomen was sutured up and the rats were put down with intraperitoneal propofol injection $(10 \mathrm{mg} / \mathrm{kg})$. Strict adherence to the regulations of the European Convention for the Protection of Vertebrate Animals used for Experimental and Other Scientific Purposes (Strasbourg, 1986) and the Directive 2010/63/ EU of the European Parliament and of the Council on the protection of animals was provided [15]. Clearance from the bioethics commission of the Ternopil National Medical University was got.

Mean arithmetic values (M) and standard deviation (m) were calculated. Source data having normal distribution, the Student's t-test was used to determine the statistical significance of various mean values. Levels of statistical significance were calculated. Changes were regarded as reliable at $\mathrm{P}<0.001$. Microsoft Excel XP (USA) and StatSoft STATISTICA program was used for calculations.

\section{RESULTS AND DISCUSSION}

The activity of LP and antioxidant protection system in experimental Pc has been found to depend on the effect on the animals of the introduced coal dust (Table 1). Pc simulation resulted in a solid increase in the content of intermediate lipid peroxidation products in the blood serum, directly related to the period of coal dust priming. At the background of 3-and 6-week priming with the coal dust, blood serum DC content increased 3.33 and 4.41 times, whereas MDA content 2.47 and 2.51 times increased. 12-week priming resulted in 5.33 and 3.05 times increase, respectively. Activity changes in the enzymes of antioxidant protection system were also related to the priming period. While after 1 -week dust priming only the tendency to changing enzymatic activity occurred, after 3-6-12-week exposure to the dust reliable decline in the activity of CAT, SOD, GPR and reliable increase in GR activity. SOD activity at the background of 3-6-12-week dust priming demonstrated 1.76, 2.42, and 6.18 times decrease. After 6 and 12 weeks of exposure to the dust, GPR activity decreased by 138.0 and $142.0 \%$, respectively, and that of CAT -88.0 and $173.0 \%$, respectively. At the background of experimental Pc, GR activity increased in 3,6 , and 12 weeks by 56.0, 94.0, and $102.0 \%$, respectively. Besides, proportional to exposure the decrease of RG content occurred. After 3-week priming, RG content decreased 2.13 times, the values for 6 -and 12 -week priming being 2.66 and 4.92 times.

In recent years, many pathogenic mechanisms of Pneumoconiosis development have been specified due to the use of various biochemical, cytochemical, and immunologic methods, as well as electron microscopy and polarography. Inhaled with the air, the dust partly accumulates on the mucous membrane of respiratory ducts, partly in the alveoli and then penetrates into lymphatic vessels of interalveolar septa and lymphatic nodes of lung roots. Dust particles up to $5 \mu \mathrm{m}$ in size are mostly aspirated, the larger 
Table 1. Effect of experimental pneumoconiosis on the indices of lipid peroxidation, and antioxidant protection system in albino rats

\begin{tabular}{|c|c|c|c|c|c|c|c|c|}
\hline $\begin{array}{l}\text { Period of } \\
\text { exposure } \\
\text { to coal dust } \\
\text { suspension }\end{array}$ & $\begin{array}{c}\text { Catalase } \\
\mathrm{mmol} / \mathrm{l}\end{array}$ & $\begin{array}{c}\mathrm{SOD} \\
\mathrm{mmol} / \\
\mathrm{min} \cdot 1\end{array}$ & $\begin{array}{c}\mathrm{RG} \\
\mathrm{mmol} / \mathrm{l}\end{array}$ & $\begin{array}{c}\text { GPR } \\
\mathrm{mmol} / \\
\min \bullet 1\end{array}$ & $\begin{array}{c}\mathrm{GR} \mathrm{mmol} / \\
\mathrm{min} \bullet 1\end{array}$ & $\begin{array}{l}\mathrm{MDA} \\
\mathrm{mmol} / 1\end{array}$ & $\begin{array}{c}\mathrm{DC} \\
\mathrm{mcmol} / 1\end{array}$ & $\begin{array}{c}\mathrm{TC} \\
\mathrm{mcmol} / 1\end{array}$ \\
\hline Intact animals & $\begin{array}{c}5.86 \pm \\
0.02\end{array}$ & $\begin{array}{c}1.36 \pm \\
0.05\end{array}$ & $\begin{array}{c}1.28 \pm \\
0.03\end{array}$ & $\begin{array}{c}0.62 \pm \\
0.04\end{array}$ & $\begin{array}{c}0.48 \pm \\
0.02\end{array}$ & $\begin{array}{c}1.44 \pm \\
0.03\end{array}$ & $\begin{array}{c}0.12 \pm \\
0.01\end{array}$ & $\begin{array}{c}0.11 \pm \\
0.01\end{array}$ \\
\hline 1 week & $5.75 \pm$ & $1.31 \pm$ & $0.79 \pm$ & $0.59 \pm$ & $0.59 \pm$ & $2.42 \pm$ & $0.36 \pm$ & $0.27 \pm$ \\
\hline$(\mathrm{n}=10)$ & 0.60 & $0.10^{*}$ & $0.01 *$ & $0.05 *$ & $0.06^{*}$ & $0.02 *$ & $0.02 *$ & $0.01 *$ \\
\hline 3 weeks & $3.48 \pm$ & $0.77 \pm$ & $0.60 \pm$ & $0.35 \pm$ & $0.75 \pm$ & $3.56 \pm$ & $0.40 \pm$ & $0.35 \pm$ \\
\hline$(\mathrm{n}=10)$ & $0.02 *$ & $0.01 *$ & $0.02 *$ & $0.01 *$ & $0.06^{*}$ & $0.20 *$ & $0.01^{*}$ & $0.01^{*}$ \\
\hline 6 weeks & $3.11 \pm$ & $0.56 \pm$ & $0.48 \pm$ & $0.26 \pm$ & $0.93 \pm$ & $3.62 \pm$ & $0.53 \pm$ & $0.38 \pm$ \\
\hline$(\mathrm{n}=10)$ & $0.02 *$ & $0.03^{*}$ & $0.03 *$ & $0.02 *$ & $0.09 *$ & $0.15^{*}$ & $0.03^{*}$ & $0.02 *$ \\
\hline 12 weeks & $2.14 \pm$ & $0.22 \pm$ & $0.26 \pm$ & $0.14 \pm$ & $0.97 \pm$ & $5.05 \pm$ & $0.64 \pm$ & $0.62 \pm$ \\
\hline$(\mathrm{n}=10)$ & $0.03 *$ & $0.02 *$ & $0.03 *$ & $0.02 *$ & $0.07 *$ & $0.30 *$ & $0.03 *$ & $0.02 *$ \\
\hline
\end{tabular}

$* \mathrm{P}<0.001-$ reliable changes regarding control animals.

particles not penetrating into the alveoli [16].

Upon getting into respiratory ducts, the dust irritates the receptor apparatus of the mucous membrane and provokes defense and adaptive reactions. Initially, they reveal themselves in the activation of the secretion activity of mucous membrane glands and ciliated epithelium, thus contributing to precipitation and removal of dust particles. Lasting and intensive dust inflow results in the development of sustainable changes in the form of subatrophic and then atrophic processes which, in fact, is a direct causative factor of chronic dust bronchitis and obstructive lung emphysema [17].

There are various pathogenic theories of lung fibrosis emergence and development in Pneumoconiosis [18]. The advocates of the mechanic theory believe that lung fibrosis is caused by dust physical properties. In particular, importance is attached to the hardness and shape of dust particles. There have been opinions that dust particles with sharp borders and angles have a damaging mechanical effect on the pulmonary tissue and provoke fibrosis at the site of their accumulation as a response.

The advocates of pathogenic toxic chemical theory regard the emergence of pneumoconiosis fibrosis from the standpoint of dust solubility in body fluids. As a chemically active substance, dust exerts a direct toxic effect on the cells. When damaged, dust crystals can form free chemical active radicals, capable of hydration with the formation of hydroxyl groups which, by easily reacting with body tissue proteins, cause their destruction with fibrosis development to follow. Noteworthy are the data indicating dust particles' capacity to adsorb various proteins on their surface, primarily globulins.

Actually, biological theories of pathogenesis, theories on the role of infection in fibrosis development included, deal with the study of systemic biological reactions on the effect of coal dust. Lung fibrosis due to the dust effect has been also attributed to the development of lymphostasis owing to the blockade of lymphatic ducts by dust particles [17].

Presently, pathogenic theories under which phagocytosis and direct effect of dust particles with chemically active radicals on the cytoplasm of the macrophages, causing damage to the membranes of intracellular organelles, are the basic mechanisms of coal dust action, are most recognized [16]. The primary reaction of the lung tissue to the dust penetration is phagocytosis of dust particles with the active involvement of macrophages. In fact, it is a reaction to a foreign body. Phagocytosis is usually accompanied by accelerated death of macrophages, released 
dust particles being again absorbed by the other macrophages. The direct relation between fibrotic process intensity and death speed of macrophages which had phagocyted dust particles was found. Macrophages' death is attributed to the toxic effect of dust on the cellular cytoplasm that leads to the disturbance of their enzyme systems. In the macrophages, which have absorbed dust particles, mitochondria degeneration occurs, accompanied by their membranes' damage [18]. Thereafter, the permeability of lysosome membranes occurs, the latter deranging the process of energy exchange in the pulmonary tissue, and then contributing to collagen excessive formation. These changes in membrane structure contribute to the decrease of cellular biosynthetic activity and lead to the decrease of redox processes, the latter, in its turn, causing distorted scleroprotein synthesis [17]. Within the first week of coal dust injection, $250 \mathrm{mg} / \mathrm{kg}$ intratracheally, morphologic changes specific of Pc occur: dust phagocyting by macrophages, interalveolar septa sclerosis, accumulation of alveolar macrophages in alveoli lumen, and formation of inflammatory infiltrates [12, 16]. Initially, chronic bronchitis with lymphohistiocytic infiltration of lymphoid follicles in bronchi walls and accumulation of a number of goblet cells in the epithelium develops that makes for irregular bronchi widening and narrowing. In the vessels, hypertrophy of endothelial cells develops alongside with growing cell nuclear components and nuclear hyperchromia. Lung structure undergoes changes through the formation of emphysema foci with sharp thinning and rupture of interalveolar septa. Peribronchial and perivascular sclerosis, as well as interalveolar septa sclerosis, develop $[12,16]$. Morphologic alveolar disorders, as well as peribronchial and perivascular sclerosis aggravate blood oxygenation processes in the lungs [8]. Damage to pulmonary structures, destruction of cellular membranes and elements are accompanied by intensified lipid peroxidation, resulting in the further destruction of cellular membranes.
Severe morphologic changes of the pulmonary tissue develop causing hypoxia and aggravation of the functional state of lungs. Clinically, it reveals itself in the reduced saturation of arterial blood and of partial oxygen pressure in the arterial blood [1].

We have observed significant increase in blood serum of the content intermediate products (MDA, DC, and TC) of lipid peroxidation at the background of suppressed SOD, CAT, GPR and increased GR activity. In our opinion, excessive activation of free radical oxidation reactions is a typical pathologic process that occurs in different hypoxia-associated diseases, supernormal formation of highly active free radical oxygen forms being the initial stage of oxidative stress development. It is regarded as proved that increasing lipid peroxidation activity is an essential pathogenic mechanism in the development of dust lung pathology. Free radicals that have been formed due to the effect on the structures, destroy phospholipids, or more precisely, unsaturated fatty acids which are integral, subjecting them to lipid peroxidation [2]. Excessive activation of the processes of chain free radical lipid oxidation leads to the tissue accumulation of lipid peroxides, fatty acid radicals, ketones, aldehydes, and ketoacids which cause damage to cellular membranes and their increased permeability, and lead to oxidative modification of the structure of proteins, enzymes, and biologically active substances [19]. The antioxidant protection system act as a regulator of lipid peroxidation state [20]. SOD, CAT, and glutathione are the main antioxidant enzymes of the system. First among the enzymes of antioxidant protection system is CAT that neutralizes superoxide anion radical and hydrogen peroxide. It can reveal its reducing activity towards small molecules, such as hydrogen peroxide and methyl-or ethyl peroxide. CAT is mostly localized in peroxisomes. Glutathione redox cycle is a central mechanism of intracellular hydroperoxides reduction, far exceeding catalase in eliminating various hydroperoxides. 
GPR is an enzyme that reduces containing hydrogen peroxide and lipid peroxides with simultaneous glutathione oxidation (GSH) $[21,22]$. GPR is 1000 times more related with hydrogen peroxide in comparison with CAT and is, therefore, regarded as a first choice in the protection of the cell from hydrogen peroxide. GPR activity increases depending on the number of emerging lipid peroxides. In this, accumulation of oxidized glutathione, as well as of mixed glutathione and protein disulfides occurs; NADP-H and then reduced glutathione level decreases. Antioxidant activity of reduced glutathione is closely related to that of glutathione system protective enzymes. In conditions of lipid peroxidation activation, the level of reduced glutathione declines, whereas that of oxidized glutathione - increases.

Our findings confirm the results of Abidi P. et al., 1999 [21], concerning tension between activity changes of different antioxidant protection system enzymes in Pc. According to Anlar H., 2017 [22], functional disorders of antioxidant protection system play a leading role both in the processes of systemic adaptation to extreme conditions and the development of more serious disorders. In some author's opinion [19, 20], primary pathogenic shifts occurring due to the formation of respiratory dust pathology are associated with the overstrain of utilization mechanisms of active oxygen forms and degree of disorders in the antioxidant protection system that largely determines the state of immune system.

It should be mentioned that lipid peroxidation products are among potential anti-inflammatory factors [19]. They play a key role in damaging vascular endothelium and are capable of suppressing endothelium-dependent vascular relaxation and of causing vasoconstriction [4]. All the above-mentioned reactions occur in $\mathrm{Pc}$ pathogenesis.

While interpreting findings, it should be mentioned that one-week action of dust, roughly corresponding to half a year man's stay in the coal mine, the solid increase in the activity of lipid peroxidation processes were observed with lacking reliable changes in the activity of the enzymes of antioxidant protection system. Probably, in this case antioxidant protection system keeps on inactivating lipid peroxidation products. Further lipid peroxidation increase at the background of 3-, 6- and 12-week exposure to the dust that corresponds to 1-, 1.5- and 3 -year stay in the mine, was accompanied by the reliable decrease in CAT, SOD, GPR activity, also alongside with simultaneous increase of GR activity. It is noteworthy that the rate of the enzymes' activity changes were the lowest at the late stage of the experiment - within 6- and 12-week exposure to the dust. It may be that 12week exposure to the dust corresponded to the phase of lung fibrosis development, at which, according to Abidi P. et al. (1999), activity of antioxidant protection enzymes declines, the latter remaining hypothetical only, requiring further research.

\section{CONCLUSIONS}

1. The development of experimental pneumoconiosis is accompanied by $1.68-5.63$ times increase in blood content of lipid peroxidation markers: malonic dialdehyde, diene conjugates, and triene conjugates depending on the duration of the disease.

2. The development of experimental pneumoconiosis is accompanied by the stable in 1.74-4.42 times decline in the activity of catalase, superoxide dismutase, and glutathione transferase alongside reliable 1.56-2.02 times increase in the activity of glutathione reductase, the changes being directly related to the duration of pneumoconiosis.

The research has been performed under the Agreement on the scientific cooperation between Pope John Paul II State Higher School (Państwowa Szkoła Wyższa im. Papieża Jana Pawła II w Białej Podlaskiej), Poland, and I. Horbachevsky Ternopil National Medical University, as an integral part of the interdepartmental scientific 
themes of I. Horbachevsky Ternopil National Medical University "Morphofunctional Basis for Adaptation Processes in Greater and Lesser Circulation under Different Corrective Influence" (State registration № 0104U004522). There is no conflict of interest.

The authors of this study confirm that the research and publication of the results were not associated with any conflicts regarding commercial or financial relations, relations with organizations and/or individuals who may have been related to the study, and interrelations of coauthors of the article.

\section{О. Олійник ${ }^{1}$, А. Сліфірчик ${ }^{1}$, О. Венгер ${ }^{2}$ \\ ВПЛИВ ЕКСПЕРИМЕНТАЛЬНОГО ПНЕВ- МОКОНІОЗУ НА ПЕРЕКИСНЕ ОКИСНЕННЯ ЛІПІДІВ ТА АКТИВНІСТЬ ФЕРМЕНТІВ АНТИОКСИДАНТНОӤ СИСТЕМИ ЗАХИСТУ У ЩУРІВ-АЛЬБІНОСІВ}

Пневмоконіоз $є$ інтерстиціальним захворюванням легень професійного генезу, що виникає при тривалому вдиханні високих концентрацій пилу та розвивається у $26,6-53 \%$ працівників, що перебувають в умовах забруднення пилом. Його особливістю $є$ невиліковність і незворотність. Експериментальний пневмоконіоз ми моделювали у 72 щурів-альбіносів ендотрахеально. ін'єкцією суспензії вугілля згідно з власною модифікацією методики Ніколенко. Активність перекисного окиснення ліпідів та ферментів антиоксидантної системи захисту була пов'язана з періодом хвороби. Залежно від тривалості захворювання, пневмоконіоз підвищував вміст малонового діальдегіду в крові в $1,68-3,05$ раза, а дієнових та триєнових кон'югатів у 2,43-5,63 раза. Залежно від фази захворювання у $1,77-4,42$ раза знижувалася активність каталази, супероксиддисмутази та глутатіонпероксидази. Водночас активність глутатіонредуктази збільшувалася у 1,56-2,02 раза. Вміст відновленого глутатіону зменшувався пропорційно тривалості захворювання. Ініціація перекисного окиснення ліпідів та пригнічена активність ферментів антиоксидантної системи можуть бути серед патогенних механізмів розвитку експериментального пневмоконіозу. Ключові слова: експериментальний пневмоконіоз; перекисне окиснення ліпідів; каталаза; супероксиддисмутаза; глутатіонпероксидаза; глутатіонредуктаза.

\footnotetext{
${ }^{1}$ Державна школа вищуої освіти Івана Павла II, Бяла-Підляска, Польщча;

${ }^{2}$ Тернопільський національний медичний університет ім. І.Я. Горбачевського, Украӥна.
}

\section{А. Олейник, А. Слифирчик, Е. Венгер \\ ВЛИЯНИЕ ЭКСПЕРИМЕНТАЛЬНОГОПНЕВ- МОКОНИОЗА НА ПЕРЕКИСНОЕ ОКИС- ЛЕНИЕ ЛИПИДОВ И АКТИВНОСТЬ ФЕР- МЕНТОВ АНТИОКСИДАНТНОЙ СИСТЕМЫ ЗАЩИТЫ У КРЫС АЛЬБИНОСОВ}

Пневмокониоз - это интерстициальное заболевание легких профессионального генеза, вызванное длительным вдыханием высоких концентраций пыли. Пневмокониоз поражает от 26,6 до 53\% профессиональных работников, которым приходится работать в среде с повышенным содержанием пыли. Особенность протекания пневмокониоза заключается в его неизлечимости и необратимости. Пневмокониоз моделировали у 72 белых крыс путем эндотрахеального введения суспензии угля в соответствии с собственной модификацией методики Николенко. Активность перекисного окисления липидов и ферментов системы антиоксидантной защиты зависела от периода болезни. Развитие экспериментального пневмокониоза приводило к повышению в крови содержания малонового диальдегида в 1,68-3,05 раза, диеновых конъюгатов и триеновых конъюгатов в 2,43-5,63 раза в зависимости от продолжительности заболевания. Наблюдали снижение активности каталазы, супероксиддисмутазы и глутатионпероксидазы в 1,77-4,42 раза, а также повышение активности глутатионредуктазы в 1,56-2,0 раза в зависимости от фазы заболевания. Содержание восстановленного глутатиона снижалось пропорционально продолжительности заболевания. Инициирование перекисного окисления липидов и подавление активности ферментов системы антиоксидантной защиты вероятно являются одними из наиболее важных патогенетических механизмов развития экспериментального пневмокониоза.

Ключевые слова: экспериментальный пневмокониоз; перекисное окисление липидов; каталаза; супероксиддисмутаза; глютатионпероксидаза; глютатионредуктаза.

\section{REFERENCES}

1. Colinet J, Rider J, Listak J, Organiscak J, Wolfe A. Best Practices for Dust Control in Coal Mining. National Institute for Occupational Safety and Health. Pittsburgh: PA; WA: DHHS (NIOSH). Publication № 2010-110; 2010.

2. Shi J, Mao L, Chen Z, Zhou S, Bian L, Sun D. Comparison of welder's pneumoconiosis with silicosis and follow-up study of welder's pneumoconiosis. Zhonghua Lao Dong Wei Sheng Zhi Ye Bing Za Zhi. 2015,Nov;33(11):826-9. [Chinese].

3. Tang H, Wang Y, Chen H, Xu J, Li B. Case fatality rate in patients with pneumoconiosis in China: a meta-analysis. Zhonghua Lao Dong Wei Sheng Zhi Ye Bing Za Zhi. 2015; 33(3):229-32. [Chinese].

4. Behn C, Araneda O, Llanos A. Hypoxia-related lipid peroxidation: evidences, implications and approaches. Respir Physiol Neurobiol. 2007;158(2-3):143-50. 
5. Cecala A, O'Brien A. Dust Control Handbook for Industrial Minerals Mining and Processing. National Institute for Occupational Safety and Health. Pittsburgh: PA; WA: DHHS (NIOSH). Publication № 2012-110; 2012.

6. Imanaka M, Suganuma N. Japanese workplace health management in pneumoconiosis prevention. J Occup Health. 2017 Mar 28;59(2):91-103.

7. Peskov S.A. Biological markers of early development of pneumoconiosis. Novosibirsk, 2000. [Russian].

8. Peskov SA, Poteryeva EL, Nikiforova NG. On prognostic value of some phenotypic markers of blood groups, reactivity of neutrophils and lipid peroxidation during pneumoconiosis. Med Tr Prom Ekol. 2002;(1):12-5. [Russian].

9. Pilipenko N. Disturbances in the system of LPO-AOD in patients with chronic obstructive pulmonary disease and pneumoconiosis of professional genesis. Actual Probl Modern Med. 2017;17:164-7. [Russian].

10. Shontsova TS, Ilderbaev OZ., Salambayeva GA. About the activity of some antioxidant enzymes in experimental pneumoconiosis. Available from: www. rusnauka.com/11_EISN_2008/Medecine/30819.doc.htm (20.04.2019). [Russian].

11. Nikolenko O Ju. An experimental approach to the reproduction of anthracosilicosis in rats. Med. Today and Tomorrow. 2013;1:132-8. [Russian].

12. Hatch GE, Raub JA, Graham JA. Functional and biochemical indicators of pneumoconiosis in mice: comparison with rats. J Toxicol Environ Health. 1984;13(4-6):487-97.

13. Gelashvili OA. A variant of the periodization of biologically similar stages of ontogenesis of humans and rats. Saratov J Med Sci Res. 2008;4:125-9. [Russian].

14. Vollhardt P, Neil E. Organic Chemistry. 6th ed. New York: W.H. Freeman \& Company; 2007.

15. European Union Directive 2010/10/63 EU on the protection of animals used for scientific purposes. Official J Eur Union (OJ) C 277; 17.11.2009.

16. Mikhailova NN, Bondarev OI. Pathomorphological changes in the vessels of the heart and lungs in pneumoconiosis. Med in the Kuzbass. 2017;(3):36-43. [Russian].

17. Jiang M, Li L, Wang Z, Zhang C. Preliminary study of exon sequence in pneumoconiosis and pneumoconiosis complicated with lung cancer using high-throughput sequencing technology. Zhang Zhonghua Lao Dong Wei Sheng Zhi Ye Bing Za Zhi. 2017;35(11):801-6. [Chinese].

18. Steenland K, Stayner L. Silica, asbestos, man-made mineral fibers, and cancer. Cancer Causes Control. 1997 May;8(3):491-503.

19. Wang P, Xie K, Wang C, Bi J. Oxidative stress induced by lipid peroxidation is related with inflammation of demyelination and neurodegeneration in multiple sclerosis. Eur Neurol. 2014;72(3-4):249-54.

20. Rauchová H, Vokurková M, Koudelová J. Hypoxiainduced lipid peroxidation in the brain during postnatal ontogenesis. Physiol Res. 2012;61(1):89-101.

21. Abidi P, Afaq F, Arif J. Chrysotile-mediated imbalance in the glutathione redox system in the development of pulmonary injury. Toxicol Lett. 1999;106(1):31-9.

22. Anlar HG, Bacanli M, İritaş S, Bal C, Kurt T, Tutkun E, Hinc Yilmaz O, Basaran N. Effects of occupational silica exposure on oxidative stress and immune system parameters in ceramic workers in Turkey. J Toxicol Environ Health A. 2017;80(13-15):688-96. 